\title{
Gene Amplification Technique
}

National Cancer Institute

\section{Source}

National Cancer Institute. Gene Amplification Technique. NCI Thesaurus. Code C20589.

This technique refers to selectively replicate DNA sequence of interest to multiple extra copies that meet the need of research or health care activity. Polymerase chain reaction (PCR), can be considered a type of man-made gene amplification process. 